\title{
Pengembangan Kaidah Fikih Fatwa Ekonomi Syariah DSN-MUI
}

\author{
Sandy Rizki Febriadi, Neneng Nurhasanah, Maman Surahman \\ Universitas Islam Bandung
}

*Correspondence address: sandyrizkifebriadi@unisba.ac.id

\section{㟒勒 \\ ISSN: 1979-4703 (p) \\ ISSN: 2527-9726 (e)}

Keywords:

Fiqh Principle, Fatwa, Sharia Economy

\begin{abstract}
A B S T R A C T
The application of figh principles to Islamic economic issues often uses general principles outside the muamalah field, even though general figh rules in the muamalah field and detailed rules have been formulated. This article aims to describe the development of fiqh principles on Islamic economic fatwas issued by the DSN-MUI from 2000 to 2019. This study uses a qualitative research approach with descriptive analysis, using a library research approach. This study's results indicate that the development of fiqh principles in the DSN-MUI fatwa can be analyzed from two perspectives. First, the ten figh rules with the most significant number are the rules "Basically all forms of muamalat are allowed, unless there are arguments that probibit them." This rule occupies several repetitions of 125 times (36\%). Then the figh rule ranks tenth with the intensity of the repetition of 8 times (2\%), namely the fiqh rule: "Every debit and credit that brings benefits is usury." Second, the DSN-MUI Fatwa Commission has used the theoretical level because its use includes: core principles, basic principles, general rules, special rules, to detailed regulations.
\end{abstract}

\section{A B S T R A K}

Penerapan kaidah fikih pada persoalan ekonomi syariah seringkali menggunakan kaidah umum di luar bidang muamalah, sekalipun kaidah fikih umum bidang muamalah dan kaidah terperinci telah dirumuskan. Artikel ini bertujuan untuk mendeskripsikan pengembangan kaidah fikih terhadap fatwa ekonomi syariah yang diterbitkan DSN-MUI tahun 2000 sampai tahun 2019. Studi ini menggunakan pendekatan qualitative research dengan analisis deskriptif, dengan menggunakan pendekatan library research. Hasil studi ini menunjukkan bahwa pengembangan kaidah fikih pada fatwa DSN-MUI dapat dianalisis dari dua sudut pandang, yaitu; Pertama, sepuluh kaidah fikih dengan jumlah terbanyak adalah kaidah "Pada dasarnya segala bentuk muamalat diperbolehkan, kecuali ada dalil yang mengharamkannya." Kaidah ini menempati jumlah pengulangan sebanyak 125 kali (36\%). Kemudian kaidah fikih yang menempati urutan kesepuluh dengan intensitas pengulangan sebanyak 8 kali $(2 \%)$, yaitu kaidah fikih: "Setiap utang piutang yang mendatangkan manfaat adalah riba." Kedua, Komisi Fatwa DSN-MUI telah menggunakan teori levelisasi karena penggunaannya telah mencakup: kaidah inti, kaidah asasi, kaidah umum, kaidah khusus, sampai dengan kaidah terperinci. 


\section{Pendahuluan}

Kajian fikih pada masa kini dihadapkan pada suatu kenyataan yang menuntut lahirnya kaidah-kaidah dalam ilmu-ilmu keislaman yang mempunyai bentuk sistematis dan melingkupi hukum yang berada di bawah naungannya. Hal ini bertujuan untuk memudahkan para mujtahid dalam merespon dan menjawab persoalan. Kaidah-kaidah hukum (fikih) tidaklah disusun dalam suatu kurun waktu tertentu (Fauzi et al, 2020). Kaidah-kaidah tersebut baru tersusun secara sistematis di kemudian hari sejalan dengan perkembangan dan pertumbuhan ijtihad di kalangan para pakar dan pendiri madzhab (Praja, 2015). Kaidah Fikih menjadi salah satu kekayaan peradaban Islam di dalam bidang hukum yang masih jarang ditulis. Berbeda dengan kekayaan peradaban Islam lainnya. Walaupun dalam bidang-bidang tersebut masih terus perlu dikaji, dikoreksi, dielaborasi, dan dikembangkan sebagai alat dalam mewujudkan Islam rabmatan lil 'alamin (Djazuli, 2016).

Imam Syafi'i merupakan pelopor dalam merumuskan kaidah sistematis melalui kerangka teoritis. Bidang ini semakin berkembang dengan lahirnya kitab ushul fikih sebagai refleksi dari kekayaan intelektual Islam. Selanjutnya para fuqaha menyederhanakan kepada kaidah umum yang memuat persoalan fikih, sehingga memudahkan seorang faqih dalam memutuskan hukum syar'i. Perkembangan tersebut terus berlanjut sampai dengan lahirnya berbagai literatur kaidah fikih dengan kecenderungan kepada madzhab tertentu, seperti Al-Karkhy dari madzhab Hanafi, Al-Izz bin Abd Al-Salam dari madzhab Syafi'i, dan Ibnu Taimiyah dari madzhab Hambali (Boukercha, 2014). Para ulama telah menaruh perhatian besar terhadap bidang muamalat dan mempunyai dorongan kuat untuk mencari kaidah-kaidah yang mengatur bidang tersebut. Dengan begitu, tidak keluar dari bingkai syariat yang Allah turunkan demi mewujudkan kemaslahatan manusia, baik secara material maupun spiritual, baik manusia sebagai makhluk individual maupun sosial, baik di masa kini maupun masa mendatang. Sebagaimana para ulama menyatakan: mashalib al-ibad fi alma'asy wa al-ma'ad (kemaslahatan manusia di dunia dan akhirat) (Al-Qardhawi, 2014). Pernyataan ini menunjukkan bahwa tujuan syariat adalah mewujudkan kemaslahatan.

Dewan Syariah Nasional (DSN) Majelis Ulama Indonesia (MUI) dalam menerbitkan fatwanya, berlandaskan kepada dalil yang kuat dari sumber utama: AlQuran dan Sunnah. Lalu dalil-dalil hukum yang disepakati maupun diperselisihkan oleh para mujtahid, kemudian menggunakan kaidah fikih. Namun dalam penerapan kaidahkaidah fikih tersebut, terdapat tiga persoalan yang berkembang. Pertama, produk-produk perbankan syariah belum menerapkan kaidah-kaidah fikih khusus. Sebagai contoh, berbagai produk perbankan syariah masih menggunakan kaidah umum seperti: al-ashlu fi al-mua'malah al ibahah (pada prinsipnya segala transaksi muamalah itu diperbolehkan). Kedua, kaidah fikih belum diterapkan secara optimal untuk memajukan sektor perbankan syariah di Indonesia dengan merumuskan produk perbankan syariah yang inovatif. Perbankan syariah diharapkan dapat menambah variasi produk pembiayaan mikro dan korporasi, trade finance, produk pembangunan infrastruktur, dan produk perbankan syariah lainnya. Ketiga, levelisasi kaidah fikih ekonomi syariah di Indonesia belum diterapkan secara berjenjang sesuai dengan cakupannya.

Berdasarkan uraian latar belakang di atas, maka penelitian ini bertujuan untuk: 
pertama, mengetahui teori kaidah fikih dan penetapan fatwa DSN-MUI. Kedua, mendeskripsikan pengembangan kaidah fikih terhadap fatwa-fatwa ekonomi syariah yang diterbitkan DSN-MUI pada tahun 2000 sampai dengan tahun 2019. Penelitian ini memiliki urgensi sebagai salah satu referensi literatur hukum Islam mengenai penerapan kaidah fikih dalam bidang ekonomi syariah. Juga menjadi panduan bagi para ulama, mujtahid dan pembuat kebijakan ekonomi syariah di Indonesia, khususnya dalam menentukan levelisasi/jenjang kaidah-kaidah fikih yang akan diterapkan sesuai dengan cakupannya.

\section{Tinjauan Pustaka}

\section{Teori Kaidah Fikih}

Allah Swt sebagai syari' yang menetapkan syari'at tidak menciptakan hukum dan aturan begitu saja. Tetapi hukum dan aturan diciptakan dengan tujuan dan maksud tertentu. Tujuan syari'at adalah kemaslahatan hamba di dunia dan akhirat. Syari'at semuanya adil, semuanya berisi rahmat, dan semuanya mengandung hikmah. Setiap masalah yang menyimpang dari keadilan, rahmat, maslahat, dan hikmah pasti bukan ketentuan syari'at (Al-Jauziyyah, 1991). Dua sumber utama hukum Islam yaitu Al-Quran maupun Hadits Nabi Muhammad Saw. merupakan pendekatan yang amat berperan dalam merumuskan suatu kaidah. Maka Kaidah Fikih merupakan kaidah yang bersifat praktis, mengikat beberapa furu' yang mempunyai kesamaan hukum. Lafadznya bisa berasal dari hadits Nabi Saw., atsar sahabat, fatwa seorang mufti, bahkan berasal dari istinbath ulama terhadap ayat-ayat Al-Quran, dan sebagainya (A. S. Abbas, 2004).

Kaidah fikih menempati kedudukan yang penting dalam hukum Islam. Karena kaidah fikih tersebut merupakan konsep yang dapat membantu seseorang dalam memahami rincian persoalan hukum melalui kaidah itu sendiri. Menurut Rachmat Syafe'I, kaidah fikih mempunyai kedudukan yang penting sebab seseorang dapat mendalami fikih dan menjadikannya mampu menganalisis berbagai masalah tanpa merasa lelah, tanpa memerlukan waktu yang panjang. Disamping itu, kebutuhan para penggali hukum fikih untuk menghafalkan kaidah semakin mendesak dikarenakan semakin kompleksnya berbagai masalah dalam kehidupan dewasa ini (Syafe'i, 1999). Keberadaan kaidah fikih (kaidah hukum) dalam Islam mempunyai keunggulan dalam merumuskan dan mengembangkan produk-produk hukum Islam yang inovatif dan sesuai dengan perkembangan zaman. Hal ini pun sebagai upaya dalam bingkai memajukan penerapan nilai-nilai hukum Islam secara bertahap di Indonesia, secara khusus memajukan bidang ekonomi syariah.

Kaidah fikih merupakan kata majemuk, terdiri dari dua kata, yaitu kaidah (qa'idah) yang berarti asas, pokok, dasar, dan fondasi. Adapun istilah fikih berarti ilmu dan pemahaman, yaitu ilmu tentang hukum perbuatan manusia yang diperoleh dari dalil-dalil syara' yang terperinci (Al-Asnawi, 1999). Al-Quran menyebutkan kata qa'idah dalam bentuk jamak yaitu qawa'id. Sebagaimana firman Allah ta'ala: 
"Dan (ingatlah), ketika Ibrabim meninggikan (membina) dasar-dasar Baitullah bersama Ismail (seraya berdoa): "Ya Tuhan kami terimalah daripada kami (amalan kami), Sesungguhnya Engkaulah yang Maba Mendengar lagi Maha Mengetabui". (QS. Al-Baqarah (2): 127).

Juga firman Allah Swt.:

"Sesungguhnya orang-orang yang sebelum mereka telah mengadakan makar, maka Allah menghancurkan rumah-rumah mereka dari fondasinya, lalu atap (rumah itu) jatub menimpa mereka dari atas, dan datanglah azab itu kepada mereka dari tempat yang tidak mereka sadari." (QS. An-Nahl (16): 26).

Kata qawa'id pada ayat tersebut memiliki arti asas, yaitu fondasi yang mendasari suatu bangunan (Azzam, 1999). Terkadang pula kaidah disandarkan kepada sesuatu yang bersifat abstrak seperti kaidah-kaidah Islam, kaidah-kaidah ilmu Nahwu, kaidah-kaidah fikih, dan kaidah-kaidah ushul. Semua kaidah tersebut disandarkan kepada sesuatu yang bersifat abstrak. (Al-Ashfahani, 1998). Sebagaimana dikemukakan di atas, kata qawa'id merupakan bentuk jamak dari kata qa'idah (kaidah). Al-Jurjani mendefinisikan istilah kaidah sebagaimana berikut: "Ketetapan yang bersifat global atau universal (kulliyyah) yang dapat mencakup beberapa partikular (juriyyah)" (Al-Jurjani, 1983). Dalam kitab Al-Asybah wa AnNadzair (As-Subki, 1991) disebutkan pengertian kaidah: "Suatu kaidah kulli (umum) yang bersesuaian terbadap juizyyahnya (bagian-bagiannya) yang banyak yang daripadanya diketahui bukum-hukum juriyyah tersebut." Dalam definisi lainnya, Muhammad Abu Zahrah menyebutkan: "Kumpulan bukum serupa yang kembali kepada analogi yang mengumpulkannya." Dari definisi tersebut, jelas bahwa kaidah itu bersifat menyeluruh (general) yang meliputi partikular (bagian-bagiannya). Dalam arti, dapat diterapkan kepada bagian-bagiannya tersebut (juriyyaat) (Djazuli, 2016).

Kaidah fikih merupakan salah satu instrument pembentuk hukum Islam yang mempertemukan materi-materi hukum yang sejenis, sehingga dengan pengertian ini maka kaidah fikih merupakan akumulasi dari hukum Islam (fikih). Ia juga merupakan pengetahuan yang melahirkan kekayaan solusi ketika ia dihadapkan kepada kasus-kasus hukum yang sangat banyak, mengingat ia dapat dikelompokkan kepada salah satu kaidah fikih saja. Selain itu Qawai'd Fighiyyah akan melahirkan kearifan dalam menerapkan hukum (Tathbiq Al-Ahkam) (Syam, 2014).Oleh karena itu pula sesungguhnya kaidah fikih merupakan sebuah karya yang berkembang seiring tahapan dan perjalanan sejarah. Artinya, kaidah fikih tidak terbentuk sekaligus melainkan melalui proses yang panjang. Formulasi dan redaksi kaidah fikih terbentuk secara gradual di era kelahiran fikih dan kebangkitannya melalui tangan-tangan para ulama besar fikih yang kompeten dalam hal takhrij dan tarjih yang diambil dari dalil-dalil nash syar'i yang umum, dasar-dasar/prinsipprinsip pada ushul fikih, analogis hukum, serta postulasi rasionalitas (Muhammad alZarqa, 1996).

Kegunaan atau urgensi kaidah fikih adalah dikarenakan fikih merupakan kumpulan berbagai macam aturan hidup yang begitu luas karena mencakup berbagai furu', karena 
itu perlu adanya usaha untuk mensistematiskan hukum-hukum tersebut dalam bentuk kaidah-kaidah kulli (universal) yang berfungsi sebagai klasifikasi masalah-masalah furu' menjadi beberapa kelompok, dan tiap-tiap kelompok itu merupakan kumpulan dari masalah-masalah yang serupa (Abbas, 2012). Disamping itu, kaidah fikih sangat relevan untuk diaplikasikan pada sekian banyak problem sosial dan problem kontemporer di masyarakat yang belum tersentuh oleh hukum Islam (Thalib, 2016). Izzudin bin Abd Salam (1999) menuturkan bahwa Kaidah Fikih merupakan jalan meraih maslahat dan menolak mafsadah. Hal ini beliau ungkapkan manakala menyampaikan tujuan dalam penulisan kitab "Qawa'id Al-Ahkam fi Mashalih Al-Anam” sebagaimana berikut:

"Maksud dari penyusunan kitab ini adalah menerangkan maslabat-maslahat ketaatan (ibadab), muamalat, dan semua perbuatan dalam usaha seseorang untuk memperolehnya, menerangkan maksud dari pelanggaran/kemadharatan agar bisa dibindari, menunjukkan maslahat-maslahat ibadah agar hamba dapat melakukannya sebaik mungkin, menjelaskan maslahat-maslahat mana yang harus didahulukan dari yang lain serta mafsadah/madharat mana yang harus diakbirkan daripada sebagian mafsadah lainnya, menerangkan apa yang termasuk dalam usaha (kemampuan) seseorang dan apa yang berada diluar kemampuannya dan tiada jalan meniju kepadanya." (Salam, 1999)

Urgensi kaidah fikih ini pernah dituturkan oleh As-Subki (1991), jika seseorang kesulitan memahami hukum-hukum cabang dan kaidah-kaidah fikih secara bersamaan, maka cukuplah baginya memahami kaidah-kaidah Fikih dan sumber-sumber pengambilannya saja. H. A. Djazuli membagi kaidah fikih berdasarkan ruang lingkup dan cakupannya menjadi lima macam, yaitu: pertama, kaidah inti yaitu meraih kemaslahatan dan menolak kemafsadatan (Djazuli, 2016). Sebagaimana Izzuddin Abd As- Salam menyatakan jalb al-mashalih wa daf al-mafasid. Kedua, kaidah-kaidah asasi yaitu kaidah-kaidah fikih yang lima (Al-Qawa'id Al-Asasiyab). Ketiga, kaidah- kaidah yang umum (Al-Qawa'id Al-'Aammah) yaitu kaidah-kaidah yang ada dibawah kaidah-kaidah asasi di atas. Keempat, kaidah-kaidah khusus (Al-Qawa'id Al-Khaashshah) yaitu kaidahkaidah yang khusus berlaku dalam bidang-bidang hukum tertentu, seperti dalam ibadah mahdah, muamalat, munakahat, peradilan dan jinayah. Kelima, kaidah rinci (Al-Qawa'id At-Tafshiliyah) yang merupakan bagian dari kaidah yang disebut pada nomor empat di atas, misalnya dalam bagian dari ibadah seperti tentang shalat saja, bagian jinayah seperti tentang sanksi (As-Subki, 1991).

\section{Klasifikasi dan Pembagian Kaidah Fikih}

Pada umumnya pembahasan kaidah fikih berdasarkan pembagian kaidah-kaidah asasiyah dan kaidah-kaidah ghair asasiyah. Kaidah asasiyah ialah kaidah yang disepakati oleh imam-imam mazhab tanpa diperselisihkan kekuatannya disebut juga sebagai kaidahkaidah induk karena hampir setiap bab dalam fiqih masuk dalam kelompok kaidah induk ini, yaitu: pertama, segala sesuatu bergantung kepada tujuannya. Kedua, kemadaratan itu harus dihilangkan. Ketiga, keyakinan tidak dapat dihilangkan oleh keraguan. Keempat, 


\section{At-Taqaddum}

Vol. 12 No. 2 (2020) 201-222

kesulitan dapat menarik kemudahan. Kelima, kebiasaan dapat dijadikan hukum. Kelima kaidah itu diringkas oleh Izzuddin bin Abd As-Salam dengan kaidah: Meraih kemaslahatan dan menolak kerusakan. Menurut Atha Mudzhar, kaidah-kaidah fikih dapat dikategorikan sebagai bagian dari elemen argument maslahah (Mudzhar, 2014). Adapun kaidah ghair asasiyah adalah kaidah yang merupakan pelengkap dari kaidah asasiyah dan keabsahannya masih diakui. Kaidah ini berjumlah 19 buah menurut Hasbi Ash-Shiddiqi, ada yang mengatakan 40 kaidah yang tidak diperselisihkan dan 20 kaidah yang diperselisihkan menurut Abdul Mujid (A. Abbas, 2012).

'Ali Ahmad An-Nadawi membagi kaidah fiqhiyah menjadi dua macam jika dilihat dari segi hubungannya dengan sumber tasyri, yaitu: pertama, kaidah-kaidah fikih yang merupakan hadis-hadis Nabi SAW, kemudian dijadikan sebagai kaidah fikih oleh para ahli fikih. Kedua, kaidah-kaidah fikih yang dibentuk dari petunjuk-petunjuk nash tasyri' umum yang mengandung illat (Al-Nadawi, 2000). Adapun H. A. Djazuli membagi kaidah fiqhiyah berdasarkan ruang lingkup dan cakupannya menjadi lima macam, yaitu: pertama, kaidah inti yaitu meraih kemaslahatan dan menolak kemafsadatan. Sebagaimana Izzuddin Abd As-Salam menyatakan jalb al-mashalih wa daf' al-mafasid. Kedua, kaidahkaidah asasi yaitu kaidah-kaidah fikih yang lima (Al-Qawa'id Al-Asasiyah). Ketiga, kaidahkaidah yang umum (Al-Qawa'id Al-'Aammah) yaitu kaidah-kaidah yang ada dibawah kaidah-kaidah asasi di atas. Keempat, kaidah-kaidah khusus (Al-Qawa'id Al-Khaashshah) yaitu kaidah-kaidah yang khusus berlaku dalam bidang-bidang hukum tertentu, seperti dalam ibadah mahdah, muamalat, munakahat, peradilan dan jinayah. Kelima, kaidah rinci (Al-Qawa'id At-Tafshiliyah) yang merupakan bagian dari kaidah yang disebut pada nomor empat di atas, misalnya dalam bagian dari ibadah seperti tentang shalat saja, bagian jinayah seperti tentang sanksi (Djazuli, 2016).

Tingkatan macam-macam kaidah itu digambarkan oleh H.A. Djazuli dalam gambaran sebagai berikut. Perlu diingat bahwa dalam memecahkan masalah itu tidak cukup dengan kembali kepada kaidah nomor satu. Tetapi harus dipastikan ruang lingkup dan cakupan masalah yang dihadapi agar tepat penggunaan kaidahnya. 


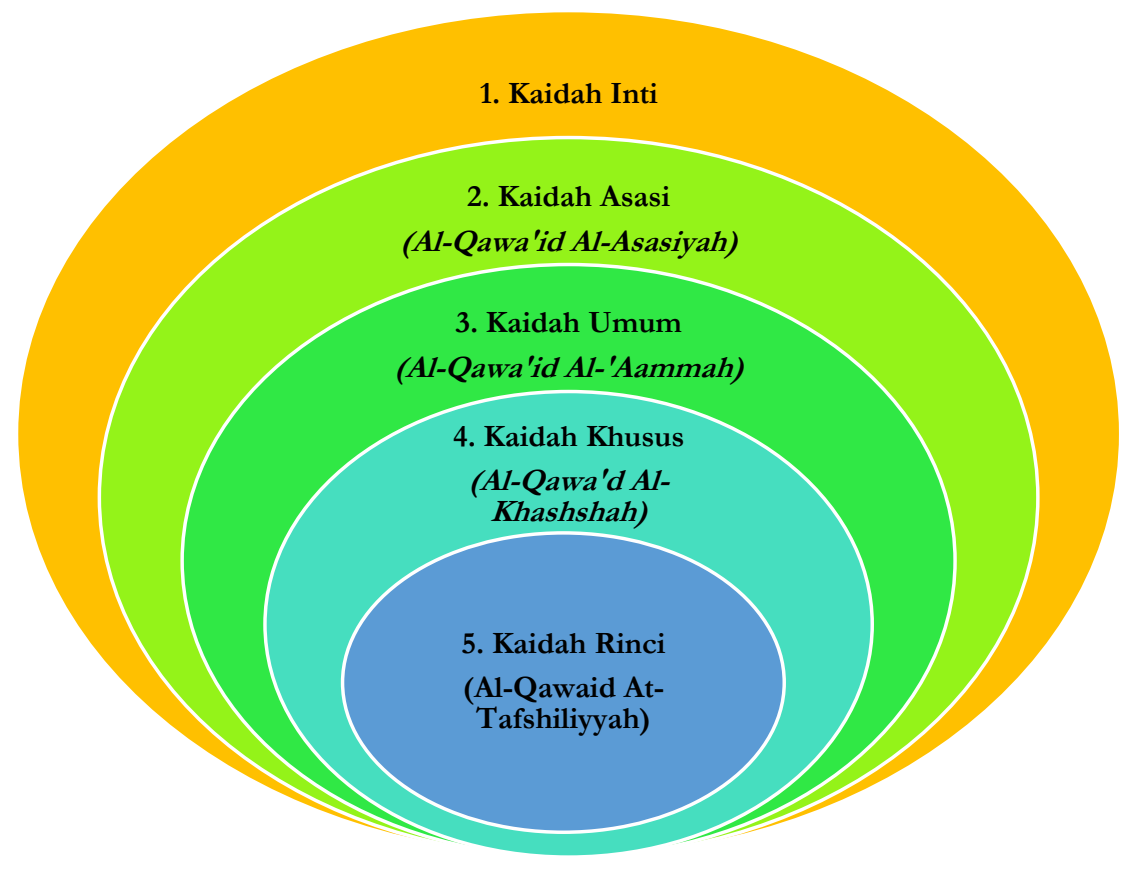

Gambar 1. Tingkatan Kaidah Fikih

\section{Manfaat dan Kegunaan Kaidah Fikih}

Berbagai ungkapan para ulama tentang urgensi, keutamaan dan manfaat mengetahui kaidah fikih ini, antara lain: "Dengan kaidah fikih, kita dapat mengetahui hakikat fikih, cara pengambilan hukum, dan rahasia-rahasia fikih, menjadi terampil dalam memahami fikih dan menghadirkannya (As-Suyuthi, 1990). Sesungguhnya kaidahkaidah fikih itu menggambarkan nilai-nilai fikih, kebaikan, keutamaan serta intinya. Dari bentuk dan uraian tentang kaidah fikih menampakkan bahwa pola pikir fikih Islam yang sangat luas dan mendalam dan tampak pula kekuatan filosofinya yang rasional serta kemampuannya di dalam mengumpulkan fikih dan mengembalikan kepada akarnya (AlRuki, 1998). Hasbi Ash-Shiddiqi menyatakan bahwa nilai seorang faqih (ahli hukum Islam) diukur dengan dalam dan dangkal pengetahuannya terhadap kaidah fikih. Karena di dalam kaidah fikih terkandung rahasia dan hikmah-hikmah fikih. Dari uraian tersebut dapat disimpulkan kegunaan-kegunaan kaidah fikih, antara lain:

Pertama, dengan mengetahui kaidah fikih kita akan mengetahui asas-asas umum fikih. Sebab kaidah-kaidah fikih itu berkaitan dengan materi fikih yang banyak sekali jumlahnya. Dengan kaidah fikih, kita mengetahui benang merah yang mewarnai fikih dan menjadi titik temu dari masalah-masalah fikih. Kedua, dengan memperhatikan kaidah fikih akan lebih mudah menetapkan hukum bagi masalah-masalah yang dihadapi, yaitu dengan memasukkan masalah tadi atau menggolongkannya kepada salah satu kaidah fikih yang ada. Ketiga, dengan kaidah fikih, seorang faqih akan lebih bijak dalam 
menerapkan fikih pada waktu dan tempat yang berbeda untuk keadaan dan adat kebiasaan yang berlainan. Sekalipun demikian, inilah keutamaan syariat Islam yang dapat diterapkan pada setiap zaman, kondisi, dan tempat. Keempat, dengan menguasai kaidahkaidah fikih dapat memberikan jalan keluar dari berbagai perbedaan pendapat di kalangan ulama atau setidaknya menguatkan pendapat yang lebih mendekati kepada kaidah-kaidah fikih. Kelima, orang yang mengetahui kaidah fikih akan mengetahui rahasia-rahasia dan semangat hukum-hukum Islam (ruh al-bukm) yang tersimpul dalam kaidah-kaidah fikih. Disamping itu, seorang faqih juga dapat mengetahui hikmah disyariatkan hukum dan menguatkan pendapatnya dalam mengambil ketetapan hukum. Keenam, orang yang menguasai kaidah fikih dan juga kaidah ushul akan mempunyai keluasan ilmu dan hasil ijtihadnya akan lebih mendekati kepada kebenaran, akurat, dan kebaikan (Djazuli, 2016).

\section{Sejarah Perkembangan Kaidah Fikih}

Imam As-Syafi'i merupakan pelopor dalam merumuskan kaidah-kaidah sistematis dalam ilmu-ilmu syar'i melalui kerangka teoritis dalam ilmu fikih. Bidang ini semakin berkembang dengan lahirnya kitab-kitab ushul fikih sebagai refleksi dari kekayaan warisan intelektual Islam. Selanjutnya para fuqaha menyederhanakan dan meringkasnya kepada kaidah umum yang dapat memuat persoalan fikih yang bersifat terperinci, sehingga memudahkan seorang faqih dalam memutuskan suatu hukum syar'i. perkembangan tersebut terus berlanjut sampai dengan lahirnya berbagai literatur kaidah fikih, baik yang bersifat umum maupun khusus dengan kecenderungan kepada madzhab tertentu, seperti Al-Karkhy dari madzhab Hanafi, Al-Izz bin Abd Al-Salam dari madzhab Syafi'i, dan Ibnu Taimiyah dari madzhab Hambali (Boukercha, 2014).

Kemudian Al-Qarafi dari madzhab Maliki dan ulama lainnya menawarkan permasalahan hukum Islam dengan pendekatan Fikih Legal Maxim atau Kaidah Fikih karena efisiensi yang ditawarkan dalam mencari solusi hukum Islam, sebagai berikut: Pertama, Kaidah Fikih mempunyai kedudukan istimewa dalam khazanah keilmuan Islam karena kepakaran seorang fakih sangat terkait dengan penguasaan kaidah fikih. Kedua, dapat menjadi landasan berfatwa. Ketiga, menjadikan ilmu fikih lebih teratur sehingga mempermudah seseorang untuk mengidentifikasi persoalan fikih yang jumlahnya sangat banyak (Al-Qarafi, 1990). Keempat, mengikat perkara yang bertebaran lagi banyak dalam kaidah-kaidah yang menyatukan sehingga lebih memudahkan untuk dihapal (Al-Nadawi, 2000). Kelima, urgensi Kaidah Fikih menggambarkan secara jelas mengenai prinsip-prinsip fikih yang bersifat umum, membuka cakrawala serta jalan-jalan pemikiran tentang fikih. Keenam, kaidah fikih mengikat berbagai hukum cabang yang bersifat praktis dengan berbagai dhawabith, yang menjelaskan bahwa setiap hukum cabang tersebut mempunyai satu manath (illat/rasio legis) dan segi keterkaitan, meskipun obyek dan temanya berbeda-beda (Al-Zarqa, 1983). Sejarah perkembangan kaidah fikih dapat dibagi kepada tiga periode. Periode pertama, masa pembentukan dan pertumbuhan. Masa ini mempunyai tiga fase, yaitu: fase Nabi Muhammad Saw., fase Sahabat, dan fase Tabiin. Periode Kedua, masa perkembangan dan pengkodifikasian 
(penyusunan) Kaidah Fikih. Ketiga, masa penyempurnaan dan kematangan.

\section{Perbedaan Kaidah Fikih dengan Kaidah Ushuliyyah}

Terdapat dua bentuk kaidah yang populer di kalangan umat Islam, yaitu kaidah ushul dan kaidah fikih. Keduanya memiliki fungsi penting dalam memutuskan persoalan hukum. Karena keduanya sama-sama berisikan kaidah, hal itu membuka pintu kerancuan di kalangsan sebagian pengkaji ushul fikih apakah kaidah fikih sama dengan kaidah ushul. Terdapat dua kriteria yang bisa dijadikan pegangan untuk membedakan antara kaidah ushul dengan kaidah fikih. Pertama, kaidah ushul digunakan untuk melakukan pengambilan hukum (istimbath) dari sumber-sumber hukum. Sementara itu, kaidah fikih digunakan untuk melakukan pemecahan masalah hukum praktis yang muncul dalam penerapan hasil istinbath dari dalil-dalil Al-Quran. Contohnya adalah bahwa menurut kaidah ushul "larangan tanpa ada petunjuk yang melunakkannya berarti haram." Larangan daging babi dalam Al-Quran berdasarkan penggunaan kaidah ushul tersebut oleh ahli fikih disimpulkan bahwa daging babi haram. Pada prakteknya muncul keadaan paceklik di mana yang ada hanya daging babi. Kalau tidak memakan daging babi, boleh jadi seseorang akan mati. Karena itu berlaku kaidah fikih "keadaan darurat membolehkan sesuatu yang dilarang" sehingga orang muslim boleh makan daging babi yang dilarang Al-Quran berdasarkan kondisi darurat. Bukan berarti orang Islam tersebut melanggar Al-Quran, melainkan bahwa kondisi yang ia hadapi memungkinkan ia berpindah dari hukum yang telah baku ke hukum lain yang didukung oleh ayat Al-Quran secara tidak langsung, yaitu larangan mencelakakan diri sendiri. Kaidah fikih disusun untuk mencari jalan keluar dari masalah-masalah hukum yang muncul dalam tataran praktis. Kedua, kaidah ushul diperoleh secara deduktif, sedangkan kaidah fikih secara induktif (Kurdi, 2011).

Penyusunan kaidah ushul, utamanya di kalangan ushul fikih mutakallimin, dilakukan tanpa melihat realitas terlebih dahulu. Kaidah dibuat dulu, baru kemudian diterapkan. Sementara itu, kaidah fikih diperoleh secara induktif, yaitu berasal dari penyelidikan pemecahan kasus-kasus fikih, baru kemudian disimpulkan kaidahnya. Karena itu, kaidah ushul umumnya bersifat kulli (berlaku kepada seluruh persoalan detail), sementara kaidah fikih umumnya bersifat aghlabi (berlaku kepada sebagian besar kasus, dengam berbagai perkecualian). Tabel berikut ini menggambarkan lebih lanjut perbedaan antara kaidah fikih (Al-Qawa'id Al-Fiqhiyyah) dan kaidah ushul (Al-Qawa'id Al-Ushuliyah) (Djazuli, 2016).

Tabel 1. Perbedaan Kaidah Fikih dan Kaidah Ushuliyyah

\begin{tabular}{cll}
\hline No & \multicolumn{1}{c}{$\begin{array}{c}\text { Al-Qawa'id Al-Ushuliyah (Kaidah } \\
\text { Ushuliyyah) }\end{array}$} & Al-Qawa'id Al-Fiqhiyyah (Kaidah Fikih) \\
\hline 1 & $\begin{array}{l}\text { Timbangan \& patokan untuk melakukan } \\
\text { istinbath hukum secara benar (Seperti: } \\
\text { hukum asal perintah adalah wajib, larangan } \\
\text { menunjukkan haram). }\end{array}$ & $\begin{array}{l}\text { Ketetapan yang bersifat general dan } \\
\text { meliputi bagian-bagian di bawahnya }\end{array}$ \\
\hline
\end{tabular}




\begin{tabular}{cll}
\hline No & \multicolumn{1}{c}{$\begin{array}{c}\text { Al-Qawa'id Al-Ushuliyah (Kaidah } \\
\text { Ushuliyyah) }\end{array}$} & Al-Qawa'id Al-Fiqhiyyah (Kaidah Fikih) \\
\hline 2 & Meliputi semua bagian & Hanya bersifat aglabiyah (keumuman) \\
\hline 3 & Cara menggali hukum syara yang praktis & $\begin{array}{l}\text { Kumpulan hukum yang serupa \& kembali } \\
\text { pada satu hukum yang sama }\end{array}$ \\
\hline 4 & Muncul sebelum furu' (cabang) & Muncul setelah furu' \\
\hline 5 & $\begin{array}{l}\text { Mengandung berbagai dalil yang rinci dan } \\
\text { memungkinkan mengeluarkan hukum dari } \\
\text { dalil tersebut. }\end{array}$ & $\begin{array}{l}\text { Menjelaskan masalah fikih yang terhimpun } \\
\text { dari dalil tadi. }\end{array}$ \\
\hline
\end{tabular}

\section{Penetapan Fatwa pada DSN-MUI}

Fatwa (ال فنتوى) menurut bahasa berarti jawaban mengenai suatu kejadian (peristiwa), yang merupakan kata bentukan sebagaimana dikatakan Zamakhsyari dalam Al-Kasysyaf dari kata ال فن ني (al-fataa/pemuda) dalam usianya, dan sebagai kata kiasan (metafora) atau isti'arah. Sedangkan pengertian fatwa menurut syara' adalah menerangkan hukum syara' dalam suatu persoalan sebagai jawaban dari suatu pertanyaan, baik si penanya itu jelas identitasnya maupun tidak, baik perseorangan maupun kolektif (Al-Qardhawi, 1997). Fatwa adalah jawaban resmi terhadap pertanyaan dan persoalan yang menyangkut masalah hukum. Fatwa berasal dari kata bahasa arab alifta', al-fatwa yang secara sederhana berarti pemberian keputusan. Fatwa bukanlah sebuah keputusan hukum yang dibuat dengan gampang, atau yang disebut dengan membuat hukum tanpa dasar (Gayo, 2011).

Menurut Imam Ibnu Mandzur di dalam Lisan Al-Arab menyatakan, Aftaabu Fi AlAmr Abaanabu Labu (menyampaikan fatwa kepada dia pada suatu perkara, maksudnya adalah menjelaskan perkara tersebut kepadanya). Wa Aftaa Al-Rajulu Fi Al-Mas'alah (seorang laki-laki menyampaikan fatwa pada suatu masalah). Wa Astaftaitubu Fïha Fa Aftaaniy Iftaa'an Wa Futaa (aku meminta fatwa kepadanya dalam masalah tersebut, dan dia memberikan kepadaku sebuah fatwa)". Perkataan fataay adalah asal dari kata futya atau fatway. Futya dan fatwa adalah dua isim (kata benda) yang digunakan dengan makna al-iftaa'. Iftaa' berasal dari kata Iftaay, yang artinya memberikan penjelasan. Secara definitif memang sulit merumuskan tentang arti ifta' atau berfatwa itu. Namun dari uraian tersebut dapat dirumuskan, yaitu: usaha memberikan penjelasan tentang hukum syara' oleh ahlinya kepada orang yang belum mengetahui”.

Adapun istilah fatwa dalam kitab Mafaahim Islamiyyah diterangkan sebagai berikut, secara literal, kata "al fatwa" bermakna jawaban atas persoalan-persoalan syariat atau perundang-undangan yang sulit. Bentuk jamaknya adalah fataawin atau fataaway. Jika dinyatakan Aftay Fi Al-Mas'alah menerangkan hukum dalam masalah tersebut. Sementara Al Iftaa' adalah penjelasan hukum-hukum dalam persoalan-persoalan syariat, undang-undang, dan semua hal yang berkaitan dengan pertanyaan-pertanyaan orang yang bertanya. Mufti adalah orang yang menyampaikan penjelasan hukum atau menyampaikan fatwa di tengah-tengah masyarakat. Menurut pengertian syariat, tidak ada 
perselisihan pendapat mengenai makna syariat dari kata al-fatwa dan al-iftaa' berdasarkan makna bahasa.

Menurut Prof. Amir Syarifuddin, fatwa atau ifta' berasal dari kata afta, yang berarti memberi penjelasan. Secara definitif fatwa yaitu usaha memberikan penjelasan tentang hukum syara' oleh ahlinya kepada orang yang belum mengetahuinya. (Mardani, 2013). Dari pengertian di atas dapat disimpulkan bahwa fatwa adalah hasil ijtihad seorang mufti sehubungan dengan peristiwa hukum yang diajukan kepadanya. Jadi fatwa lebih khusus dari pada fikih atau ijtihad secara umum. Karena boleh jadi fatwa yang dikeluarkan seorang mufti, sudah dirumuskan dalam fikih, hanya belum dipahami oleh peminta fatwa. Diantara dasar yang menjadi landasan hukum fatwa dan syarat-syarat seorang mufti, yaitu: pertama, Al-Quran Surat An-Nahl (16): 43, Allah ta'ala berfirman:

"Dan Kami tidak mengutus sebelum kamu, kecuali orang-orang lelaki yang Kami beri wabyu kepada mereka; maka bertanyalah kepada orang yang mempunyai pengetahuan jika kamu tidak. mengetabui." (Qs. An-Nahl (16): 43).

Kedua, Hadits Nabi Saw.,

'Dari Ibnu Abbas bahwa Sa'ad Bin 'Ubadah meminta fatwa kepada Nabi Saw., yaitu dia mengatakan: "Sesunggubnya ibuku meninggal dunia padahal beliau mempunyai keewajiban nadzar yang belum ditunaikannya?" Lalu Rasulullah Saw. menjawab: "Tunaikan nadzar itu atas nama ibumu". (HR. Abu Daud).

Mufti (هم ف تنى) berkedudukan sebagai pemberi penjelas tentang hukum syara' yang harus diketahui dan diamalkan oleh umat. Umat akan selamat bila ia memberi fatwa yang benar dan akan sesat bila ia salah dalam berfatwa, ia harus memiliki syarat-syarat sebagai berikut: Pertama, syarat umum. Ia harus seorang mukallaf yaitu muslim, dewasa, dan sempurna akalnya. Kedua, syarat keilmuan. Ia harus ahli dan mempunyai kemampuan untuk berijtihad, seperti pengetahuan bahasa, pengetahuan Al-Quran dan Sunnah Nabi, ijma', dan pengetahuan ushul fikih, dan tujuan hukum. Ketiga, syarat-syarat kepribadian yaitu adil, dapat dipercaya, dan mempunyai moralitas. Syarat ini harus dimiliki seorang mufti karena ia secara langsung akan menjadi panutan masyarakat. Keempat, syarat pelengkap. Ia harus mempunyai keteguhan niat, tenang jiwanya, hasil fatwanya tidak membingungkan atau menimbulkan kontroversi dan dikenal di tengah umat (Idris, 2007).

Terdapat persamaan dan juga perbedaan antara fatwa dan putusan pengadilan. Adapun persamaan keduanya ialah masing-masing dari hakim dan mufti harus mempunyai dua pengetahuan: pertama, mengetahui kejadian atau peristiwa yang hendak diberikan fatwa atau diberikan putusan. Kedua, mengetahui hukum syara'. Adapun sisi perbedaan antara fatwa dan putusan pengadilan ialah: Pertama, memberi fatwa lebih luas lapangannya dari pada memberi putusan, karena memberi fatwa menurut pendapat sebagai ulama, boleh dilakukan oleh orang merdeka, budak belian (hamba sahaya), lelaki, wanita, famili dekat, famili jauh, orang asing dan teman sejawat. Sedang putusan hanya 
diberikan oleh orang merdeka yang lelaki dan tidak ada sangkut paut kekeluargaan dengan yang bersangkutan. Kedua, Putusan hakim berlaku untuk penggugat dan tergugat, berbeda dengan fatwa. Fatwa boleh diterima boleh tidak. Ketiga, Putusan hakim yang berbeda dengan pendapat mufti, dipandang berlaku dan fatwa mufti tidak dapat membatalkan putusan hakim, sedangkan putusan hakim dapat membatalkan fatwa mufti. Keempat, Mufti tidak dapat memberi putusan terkecuali apabila dia telah menjadi hakim. Berbeda dengan hakim, dia wajib memberi fatwa bila telah merupakan suatu keharusan dan boleh memberi fatwa apabila belum merupakan suatu keharusan. Golongan ulama Syafi'iyah dan Hambaliyah berpendapat bahwa hakim tidak boleh memberi fatwa pada masalah-masalah yang mungkin akan dimajukan kepada pengadilan. Karena mungkin putusannya nanti berbeda dengan fatwanya, akan timbul kesulitan baginya. Karenanya Syuraih berkata "Saya memutuskan perkara diantara kamu, bukan memberikan fatwa (Al-Shiddiqy, 1994).

Dewan Syariah Nasional adalah dewan yang dibentuk oleh Majlis Ulama Indonesia (MUI) untuk menangani masalah-masalah yang berhubungan dengan aktivitas lembaga keuangan syariah. Badan Pelaksanaan Harian Dewan Syariah Nasional (BPH DSN) adalah badan yang sehari-hari melaksanakan tugas DSN. Dewan Pengawas Syariah adalah badan yang ada di lembaga keuangan syariah dan bertugas mengawasi pelaksanaan keputusan DSN di lembaga keuangan syariah. Adapun tugas DSN adalah sebagai berikut: Pertama, menumbuh-kembangkan penerapan nilai-nilai syariah dalam kegiatan perekonomian pada umumnya dan keuangan pada khususnya. Kedua, mengeluarkan fatwa atau jenis-jenis kegiatan keuangan. Ketiga, mengeluarkan fatwa atas produk dan jasa keuangan syariah. Keempat, mengawasi penerapan fatwa yang telah dikeluarkan (Sam, 2014).

Dewan Syariah Nasional (DSN) memiliki wewenang sebagaimana berikut: pertama, mengeluarkan fatwa yang mengikat Dewan Pengawas Syariah di masing-masing lembaga keuangan syariah dan menjadi dasar tindakan hukum pihak terkait. Kedua, mengeluarkan fatwa yang menjadi landasan bagi ketentuan atau peraturan yang dikeluarkan oleh instansi yang berwenang, seperti (kementerian keuangan) dan Bank Indonesia. Ketiga, memberikan rekomendasi dan/atau mencabut rekomendasi namanama yang akan duduk sebagai Dewan Pengawas Syariah pada suatu Lembaga Keuangan Syariah. Keempat, mengundang para ahli untuk menjelaskan suatu masalah yang diperlukan dalam pembahasan ekonomi syariah, termasuk otoritas moneter/lembaga keuangan dalam maupun luar negeri. Kelima, memberikan peringatan kepada Lembaga Keuangan Syariah untuk menghentikan penyimpangan dari fatwa yang telah dikeluarkan oleh Dewan Syariah Nasional. Keenam, mengusulkan kepada instansi yang berwenang untuk mengambil tindakan apabila peringatan tidak diindahkan (Berlianti, 2001).

Dewan Pengawas Syariah memiliki tugas utama sebagaimana berikut: Pertama, Dewan syariah melakukan pengawasan secara periodik pada lembaga keuangan syariah yang berada di bawah pengawasannya. Kedua, Dewan Pengawas Syariah berkewajiban mengajukan usulan-usulan pengembangan lembaga keuangan syariah kepada pimpinan lembaga yang bersangkutan dan kepada Dewan Syariah Nasional. Ketiga, Dewan 
Pengawas Syariah melaporkan perkembangan produk dan operasional lembaga keuangan yang diawasinya kepada Dewan Syariah Nasional sekurang-kurangnya dua kali dalam satu tahun anggaran. Keempat, Dewan Pengawas Syariah merumuskan permasalahan-permasalahan yang memerlukan pembahasan Dewan Syariah Nasional. (Sam, 2014). Oleh karena itu kepatuhan kepada aspek-aspek syariah menjadi keniscayaan bagi DPS, sebagaimana disebutkan: "DPS must pay attention to the sharia compliant aspects. Because the understanding of sharia by stakeholders, directors, and commissioners must be same, synergy and integration" (Imaniyati, et. al., 2017). Secara umum, petunjuk prosedur penetapan fatwa MUI dapat dikemukakan sebagai berikut: Pertama, dasar umum dan penetapan fatwa:

1. Penetapan fatwa didasarkan pada Al-Qur'an, sunah (hadits), ijma', dan qiyas serta dalil lain yang mu'tabarah.

2. Aktifitas penetapan fatwa dilakukan secara kolektif oleh suatu lembaga yang dinamakan komisi fatwa.

3. Penetapan fatwa bersifat responsif, proaktif, dan antisipatif. (Sam, 2014)

\section{Kedua, Metode Penetapan Fatwa DSN MUI:}

1. Sebelum fatwa ditetapkan hendaklah ditinjau lebih dahulu pendapat para imam mazhab dan ulama yang mu'tabar tentang masalah yang akan difatwakan tersebut, secara seksama berikut dalil-dalilnya.

2. Masalah yang jelas hukumnya hendaklah disampaikan sebagaimana adanya.

3. Dalam masalah yang terjadi khilafiyah di kalangan mazhab, maka: Penetapan fatwa didasarkan pada hasil usaha penemuan titik temu diantara pendapatpendapat ulama melalui metode al-jam'u wa at-tawfiq; Jika usaha penemuan titik temu tidak berhasil maka dilakukan, penetapan fatwa didasarkan pada hasil tarjih melalui metode muqaranah dengan menggunakan kaidah-kaidah ushul fikih muqaran.

4. Dalam masalah yang tidak ditemukan pendapat hukumnya dikalangan mazhab, penetapan fatwa didasarkan pada hasil ijtihad jama'iy (kolektif) melalui metode bayaniy, ta'liliy (qiyasiy, istibsaniy, ilhaqy), istishlaby, dan sadd adz-dzari'ah.

5. Penetapan fatwa harus senantiasa memperhatikan kemaslahatan umum (mashalih 'ammah) dan maqasid asy-syariah (Sam, 2014).

DSN-MUI menggunakan tiga pendekatan dalam memutuskan fatwa yakni Pendekatan nash qath'i, pendekatan qauli dan pendekatan manhaji. Pendekatan pertama dilakukan dengan berpegang teguh pada Al-Qur'an atau Hadis. Pendekatan kedua qauli, pendekatan dalam proses penetapan fatwa berdasarkan pada pendapat para imam madzhab dalam kitab fiqih terkemuka. Ketiga, yaitu manhaji, pendekatan yang menggunakan kaidah ushuliyah dan kaidah fiqhiyah (Fatoni, 2012). 


\section{Metode Penelitian}

Penelitian ini merupakan penelitian kepustakaan atau library research, yang dilakukan dengan mencari data dari buku, jurnal, peraturan perundang-undangan, dan tulisan-tulisan ilmiah lainnya. Pada penelitian ini akan diteliti teori kaidah fikih dan penerapannya pada fatwa-fatwa DSN-MUI dengan referensi ayat-ayat Al-Quran, Hadits, dan pemikiran-pemikiran para ulama mazhab. Dalam penelitian ini penulis menggunakan metode yuridis normatif yaitu penelitian hukum yang mempergunakan sumber data sekunder. dengan menyusun kerangka konsepsional, merumuskan ketentuan yang terdapat dalam Fikih Islam bersumber dari al-Qur'an dan hadits yang berkaitan dengan pengembangan kaidah fiqih terhadap fatwa DSN-MUI. Secara operasional penelitian yuridis normatif dilakukan dengan penelitian kepustakaan (Library Reaseach).

Objek pada penelitian ini adalah kaidah fikih yang digunakan dalam fatwa- fatwa DSN-MUI. Alat analisis atau patokan yang digunakan yaitu teori kaidah fikih. Variabel dan definisi operasional yang akan digunakan meliputi: Pertama, kaidah fikih adalah ketentuan universal yang memberikan pengetahuan tentang berbagai hukum beserta bagian-bagiannya. Kaidah fikih merupakan ketentuan universal yang bersesuaian dengan bagian-bagiannya serta dapat dipahami hukumnya dari perkara-perkara tersebut. Dewan Syariah Nasional-Majelis Ulama Indonesia (DSN-MUI) dibentuk dalam rangka mewujudkan aspirasi umat Islam mengenai masalah perekonomian. DSN-MUI mempunyai visi Memasyarakatkan ekonomi syariah dan mensyariahkan ekonomi masyarakat. Adapun misinya ialah menumbuhkembangkan ekonomi syariah dan lembaga keuangan/bisnis syariah untuk kesejahteraan umat dan bangsa. Fatwa yang dikeluarkan Dewan Syariah Nasional-Majelis Ulama Indonesia (DSN-MUI) merupakan hukum positif yang mengikat. Sebab, keberadaannya sering dilegitimasi lewat peraturan perundang-undangan oleh lembaga pemerintah, sehingga harus dipatuhi pelaku ekonomi syariah.

Aktivitas penelitian membutuhkan sesuatu yang baru, hal ini sering disebut dengan 'state of the art yang meliputi siapa saja hingga yang paling terakhir meneliti, di mana dan apa persoalannya, metode yang digunakan, dan apa hasil penelitiannya. Maka penelitian mengenai Pengembangan Kaidah Fikih Terhadap Fatwa Ekonomi Syariah Yang Diterbitkan Oleh DSN-MUI Tahun 2000 Sampai Tahun 2019 merupakan penelitian yang baru. Masalah tersebut berkaitan dengan penggunaan kaidah fikih pada fatwa DSN-MUI yang dimulai dari fatwa pertama (01/DSN-MUI/IV/2000 tentang Giro) sampai dengan fatwa terakhir (130/DSN-MUI/X/2019 tentang Pedoman bagi Lembaga Penjamin Simpanan dalam Pelaksanaan Penanganan atau Penyelesaian Bank Syariah yang Mengalami Permasalahan Solvabilitas).

Berdasarkan penelusuran terhadap penelitian-penelitian tersebut, penulis menyimpulkan bahwa penelitian-penelitian di atas mempunyai objek yang berbeda. Perbedaan itu terlihat pada fokus penelitian yang dilakukan, yaitu mengkaji aspek Pengembangan Kaidah Fikih Terhadap Fatwa-fatwa Ekonomi Syariah Yang Diterbitkan Oleh DSN-MUI Pada Tahun 2000 Sampai Dengan Tahun 2019. Secara rinci, perbedaan 
penelitian ini dengan penelitian-penelitian sebelumnya, antara lain: pertama, variabel penelitian yang berbeda; kedua, fokus penelitian pada kajian kaidah fikih aplikatif dalam fatwa-fatwa DSN-MUI dengan rentang tahun terbit fatwa sebagai batasannya. Ketiga, metode penelitian yang digunakan berbeda dengan penelitian sebelumnya.

\section{Hasil dan Pembahasan}

\section{Pengembangan Kaidah Fikih Terhadap Fatwa Ekonomi Syariah DSN-MUI}

Akad yang diterapkan oleh bank syariah dapat dibagi ke dalam enam pola. Pertama, titipan, seperti: wadi'ah yad amanah dan wadi'ab yad dhamanah. Kedua, pinjaman, seperti: qardh atau qardhul hasan. Ketiga, bagi hasil, seperti mudharabah dan musyarakah. Keempat, jual beli, seperti: murababah, salam, dan istishna. Kelima, sewa, seperti: ijarah dan ijarah muntahiya bittamlik. Keenam, pola lainnya, seperti wakalah, kafalah, hiwalah, ujrah, sharf, dan rahn. Secara umum, penetapan fatwa oleh DSN-MUI didasarkan pada Al-Qur'an, sunnah (hadits), ijma', dan qiyas serta dalil lain yang mu'tabarah seperti kaidah- kaidah fikih dan pendapat-pendapat ulama. DSN-MUI menggunakan 47 (empat puluh tujuh) kaidah fikih dalam fatwa yang diterbitkan sejak tahun 2000 sampai dengan tahun 2019. Penggunaan kaidah tersebut dapat dilihat pada tabel berikut ini:

Tabel 2 : Penggunaan dan Pengulangan Kaidah Fikih

\begin{tabular}{|c|c|}
\hline $\begin{array}{c}\text { Jumlah } \\
\text { Pengulangan }\end{array}$ & Kaidah Fikih \\
\hline 125 & الأصل في المعاملات الإباحة إلا أن يال دليل على تحريمها \\
\hline 35 & الضرر يزّال \\
\hline 29 & الحاجة قد تنزل منزلة الضرورة \\
\hline 28 & تصرف الإمام على الرعية منوط بالمصلحة \\
\hline 27 & الثابت بالعرف كالثثابت بالشرع \\
\hline 26 & أينما وجدت المصلحة فثم حكم الله \\
\hline 25 & درء المفاسد مقدم على جلب المصالح \\
\hline 24 & الضرر يدفع بقر الإمكان \\
\hline 20 & المشقة تجلب التيسير \\
\hline 8 & كل قرض جر منفعة فهو ربا \\
\hline 6 & العادة محكمة \\
\hline 4 & ما أدى إلى الحرام فهو حرام \\
\hline 3 & الحكم يدور مع العلة وجودا وعدما \\
\hline 3 & المعلق بالشرط يجب ثبوته عند ثبوت الشرط \\
\hline 3 & إن للزمن حصة من الثمن \\
\hline
\end{tabular}




\section{At-Taqaddum}

Vol. 12 No. 2 (2020) 201-222

Jumlah

Pengulangan
Kaidah Fikih

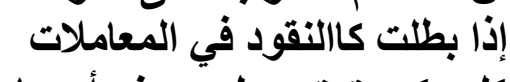

أن الأحكام المترتبة على العوائد تدور معها كيفما دارت، وتبطل معها

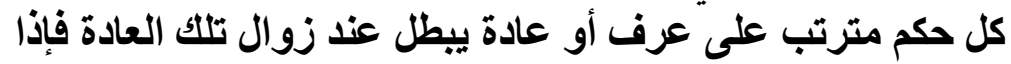
تغيرت تغير الحكم

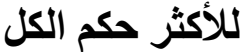

الأصل إلحاث الفرد بالأعم الأغلب دون النادر

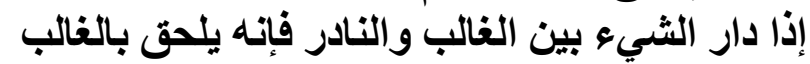
المواعيد بصور التعاليق تكون لازمة التابئ

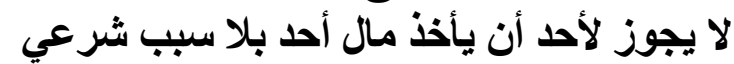
التابع تابع لاعن من شرط على نفسه طابع نائعا غير مكره فهو عليه

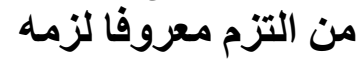

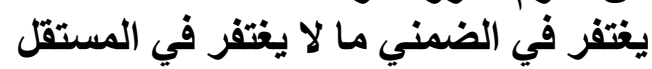

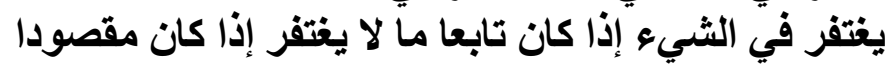

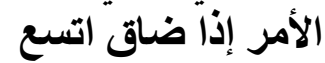
ما حرم فعله حرم طلبه الفيه الضرورات تبيح المحظور ملهات

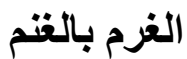
إن الثتراط الضمان على الأمين باطل الحاجة لا تحق لاجبر لأحد أن يأخذ مال غيره

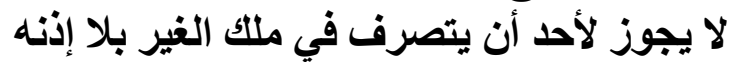

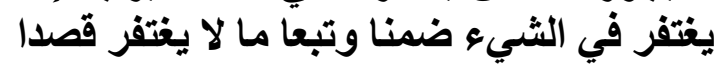

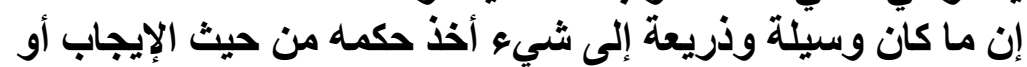

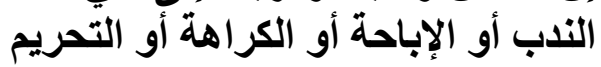

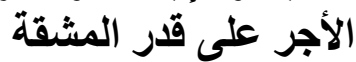

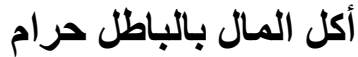

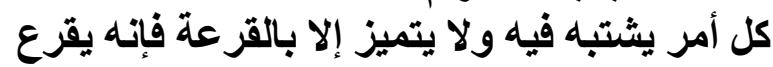

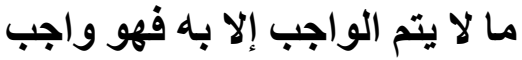

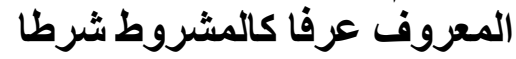
المعروف بين التجار كالمشروط بروط بينهم

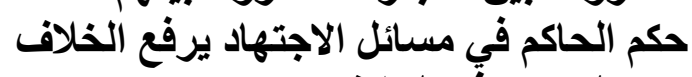

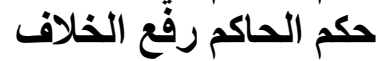
العبرة في العقود للمقاصد والفاف والمعاني لا للألفاظ والمباني 
Jumlah

Pengulangan

\section{Kaidah Fikih}

للوسائل أحكام المقاصد

\section{Total}

Pengulangan

Kaidah :
Total Penggunaan Kaidah Fikih :

47

Tabel dua tersebut menunjukkan intensitas pengulangan penggunaan kaidah fikih pada fatwa yang diterbitkan oleh DSN-MUI. Kaidah yang menyatakan:

$$
\text { الأصل في المعاملات الإباحة إلا أن بدل دليل على تحريمها }
$$

"Pada dasarnya segala bentuk muamalat diperbolebkan, kecuali ada dalil yang mengharamkannya." Kaidah ini menempati peringkat pertama dengan jumlah pengulangan terbanyak, yaitu sebanyak 125 kali. Jika data pada tabel dua diatas dibatasi berdasarkan sepuluh kaidah dengan intensitas pengulangan terbanyak maka akan didapati data sebagaimana berikut pada tabel tiga berikut ini:

Tabel 3. Sepuluh Kaidah Fikih Dalam Fatwa DSN-MUI Dengan Jumlah Intensitas Pengulangan Terbanyak

\begin{tabular}{|c|c|}
\hline $\begin{array}{c}\text { Jumlah } \\
\text { Pengulangan }\end{array}$ & Kaidah Fikih \\
\hline 125 & الأصل في المعاملات الإباحة إلا أن يدل دليل على تحريمها \\
\hline 35 & الضرر يزّال \\
\hline 29 & الحاجة قد تنزل منزلة الضرورة \\
\hline 28 & تصرف الإمام على الرعية منوط بالمصلحة \\
\hline 27 & الثابت بالعرف كالثثابت بالشرع \\
\hline 26 & أينما وجدت المصلحة فثم حكم الله \\
\hline 25 & درء المفاسد مقدم على جلب المصالح \\
\hline 24 & الضرر يدفع بقدر الإمكان \\
\hline 20 & المشقة تجلب التيسير \\
\hline 8 & كل قرض جز منفعة فهو ربا \\
\hline $\begin{array}{c}\text { Total } \\
\text { Pengulangan: } \\
347\end{array}$ & Total Kaidah: 10 \\
\hline
\end{tabular}

Kemudian data tersebut disajikan dalam bentuk diagram lingkaran atau pie chart sebagai bentuk visualisasi data dalam lingkaran yang dibagi menjadi irisan-irisan yang mewakili nilai numerik suatu data. Maka akan diperoleh visualisasi sebagaimana berikut: 


\section{At-Taqaddum}

Vol. 12 No. 2 (2020) 201-222

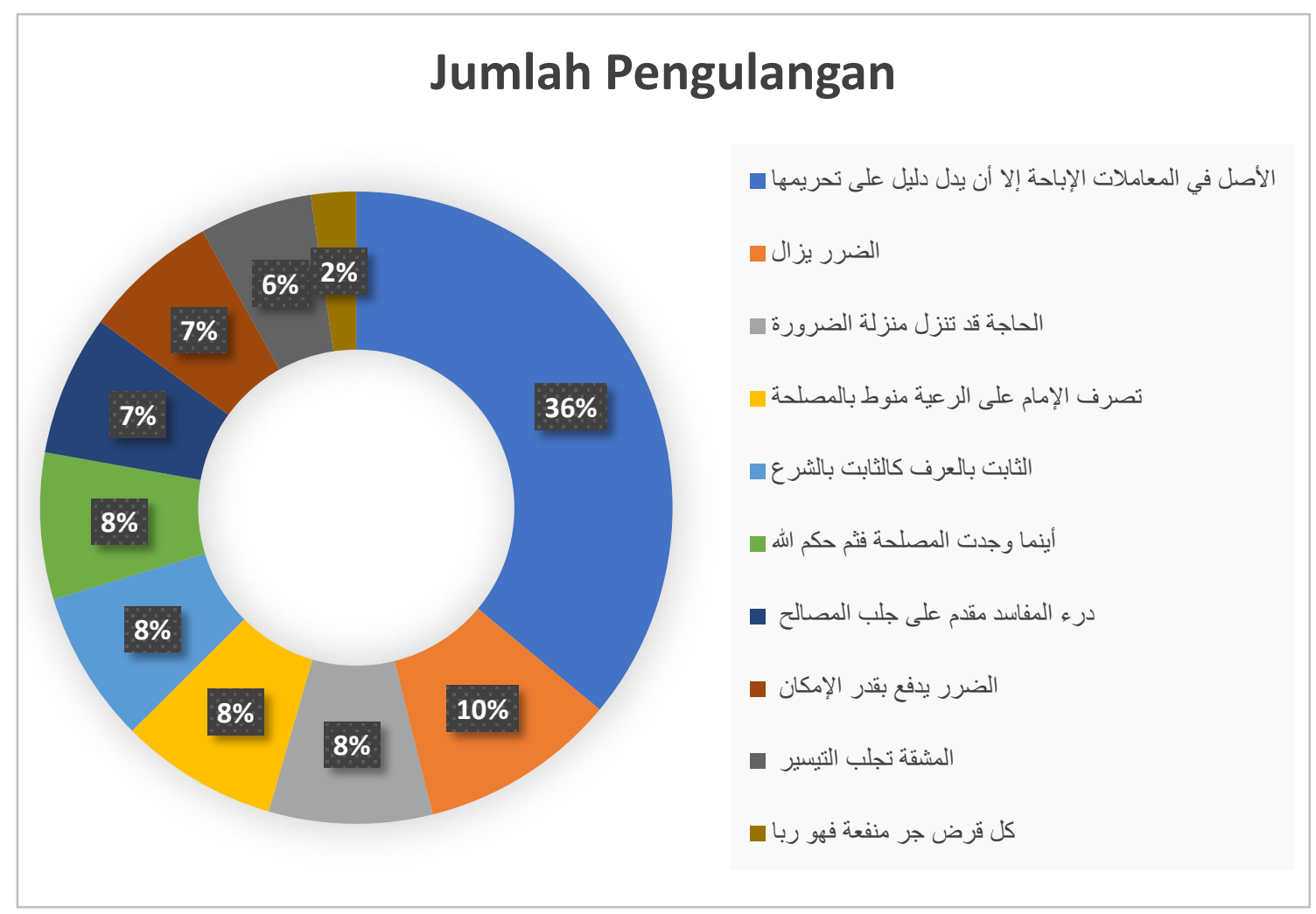

Gambar 2 : Sepuluh Kaidah Fikih Dengan Jumlah Intensitas Pengulangan Terbanyak

Berkenaan pengembangan kaidah fikih pada fatwa DSN-MUI melalui data-data tersebut dapat dianalisis dari dua sudut pandang. Pertama, sepuluh kaidah fikih dengan jumlah terbanyak dimulai dengan kaidah;

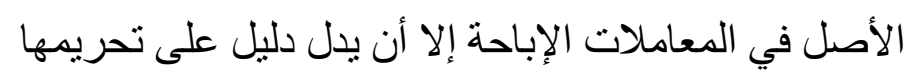

"Pada dasarnya segala bentuk muamalat diperbolebkan, kecuali ada dalil yang mengharamkannya."

Kaidah ini menempati jumlah pengulangan sebanyak 125 kali atau $36 \%$. Kemudian kaidah fikih yang menempati urutan kesepuluh dengan intensitas pengulangan sebanyak 8 kali atau $2 \%$, yaitu kaidah fikih:

$$
\text { كل قرض جر منفعة فهو ربا }
$$

"Setiap utang piutang yang mendatangkan manfaat (bagi muqridh) adalah riba." 
Kedua, jika dianalisis berdasarkan teori levelisasi kaidah fikih yang dikemukakan oleh H.A. Djazuli, maka sepuluh kaidah fikih tersebut dapat diklasifikasikan sebagaimana berikut:

Tabel 4 : Klasifikasi Kaidah Fikih

\begin{tabular}{|c|c|c|}
\hline $\begin{array}{c}\text { Jumlah } \\
\text { Pengulangan }\end{array}$ & Kaidah Fikih & Klasifikasi \\
\hline 125 & الأصل في المعاملات الإباحة إلا أن يدل دليل & $\begin{array}{c}\text { Kaidah Khusus (Bidang } \\
\text { Muamalah) }\end{array}$ \\
\hline 35 & الض & Kaidah Khamsah/Asasi \\
\hline 29 & الحاجة قة & Kaidah Umum \\
\hline 28 & الرعية منوط بالمصلحة & Kaidah Umum \\
\hline 27 & الثابت بالعرف كال & Kaidah Umum \\
\hline 26 & أينما وجدث المصلحة فثم حكم الله & Kaidah Umum \\
\hline 25 & درع المفاسد مقد & Kaidah Inti \\
\hline 24 & الضرر يدفع بقة & Kaidah Umum \\
\hline 20 & 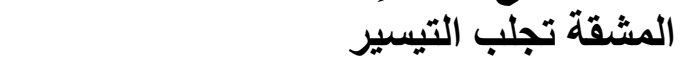 & Kaidah Khamsah/Asasi \\
\hline 8 & كل قرض جر منفعة فهو ربا & Kaidah Rinci \\
\hline
\end{tabular}

Dari tabel empat di atas dapat dipahami bahwa Fatwa DSN-MUI telah menggunakan teori levelisasi. Penggunaan kaidah inti, kaidah asasi, kaidah umum, kaidah khusus, sampai dengan kaidah terperinci, hal ini menunjukkan penggunaan kaidah secara berjenjang dan utuh yang melingkupi kelima jenis kaidah berdasarkan ruang lingkupnya. Maka kaidah yang paling banyak digunakan menunjukkan cakupan kaidah itu yang luas pada bidang muamalah. Hal ini sesuai dengan teori kaidah fikih yang diartikan sebagai ketetapan yang bersifat global atau universal yang dapat mencakup beberapa partikular. Kaidah fikih merupakan ketentuan universal yang memberikan pengetahuan tentang berbagai hukum beserta bagian-bagiannya. Pengembangan kaidah fikih pada fatwa DSN-MUI terlihat juga dari jumlah intensitas kaidah fikih yang digunakan berdasarkan tahun terbit fatwa. Pada awal-awal tahun 2000 terdapat hanya satu kaidah yang digunakan dalam sebuah fatwa, kemudian pada tahun-tahun berikutnya bertambah beberapa kaidah dalam sebuah fatwa. Sampai dengan tahun 2019 terdapat fatwa No. 130 yang memunculkan 11 (sebelas) kaidah dalam fatwa tersebut.

\section{Kesimpulan}

Berdasarkan penelitian yang dilakukan dapat disimpulkan bahwa: pertama, kaidah fikih merupakan ketetapan yang bersifat global atau universal yang dapat mencakup 


\section{At-Taqaddum}

Vol. 12 No. 2 (2020) 201-222

beberapa partikular. Kaidah fikih ialah ketentuan universal yang memberikan pengetahuan tentang berbagai hukum beserta bagian-bagiannya. Dewan Syariah Nasional adalah dewan yang dibentuk oleh Majlis Ulama Indonesia (MUI) untuk menangani masalah-masalah yang berhubungan dengan aktivitas lembaga keuangan syariah. Secara umum, petunjuk prosedur penetapan fatwa MUI dapat dikemukakan sebagai berikut: Pertama, dasar umum dan penetapan fatwa: pertama, penetapan fatwa didasarkan pada Al-Qur'an, sunah (hadis), ijma', dan qiyas serta dalil lain yang mu'tabarah. Kedua, aktifitas penetapan fatwa dilakukan secara kolektif oleh suatu lembaga yang dinamakan komisi fatwa. Ketiga, penetapan fatwa bersifat responsif, proaktif, dan antisipatif. Kedua, pengembangan kaidah fikih pada fatwa DSN-MUI dapat dianalisis dari dua sudut pandang. Pertama, 10 kaidah fikih dengan jumlah terbanyak dimulai dengan kaidah "Pada dasarnya segala bentuk muamalat diperbolehkan, kecuali ada dalil yang mengharamkannya." Kaidah ini menempati jumlah pengulangan sebanyak 125 kali atau $36 \%$. Kemudian kaidah fikih yang menempati urutan kesepuluh dengan intensitas pengulangan sebanyak 8 kali atau 2\%, yaitu kaidah fikih: "Setiap utang piutang yang mendatangkan manfaat (bagi muqridh) adalah riba." Kedua, jika dianalisis berdasarkan teori levelisasi kaidah fikih yang dikemukakan oleh H.A. Djazuli, maka bidang Fatwa DSN-MUI telah menggunakan teori levelisasi. Karena penggunaannya telah mencakup: kaidah inti, kaidah asasi, kaidah umum, kaidah khusus, sampai dengan kaidah terperinci. Kaidah yang paling banyak digunakan menunjukkan cakupan kaidah itu yang luas pada bidang muamalah. Pengembangan kaidah fikih pada fatwa DSN-MUI terlihat juga dari jumlah kaidah fikih yang digunakan berdasarkan tahun terbit fatwa. Pada awal-awal tahun 2000 terdapat hanya satu kaidah yang digunakan dalam sebuah fatwa, kemudian pada tahun-tahun berikutnya bertambah beberapa kaidah dalam sebuah fatwa. Sampai dengan tahun 2019 terdapat fatwa No. 130 yang memunculkan 11 (sebelas) kaidah dalam fatwa tersebut.

\section{Daftar Pustaka}

Abbas, A. (2012). Kaidah-kaidah Fiqh Muamalah dan Aplikasinya dalam Ekonomi Islam dan Perbankan Syariah. Jakarta: Direktorat Pendidikan Tinggi Islam dan Direktorat Jenderal Pendidikan Islam Kementerian Agama RI.

Abbas, A. S. (2004). Qawa'id Fiqhiyyah Dalam Persepektif Fiqh. Jakarta: Angelo Media.

Al-Asnawi, A. A.-H. (1999). Nihayat As-Sul Syarb Minhaj Al-Wusul. Beirut: Daar AlKutub Al-'Tlmiyyah.

Al-Jauziyyah, I. Q. (1991). I'lam Al-Munaqqi'in 'an Rabb Al-'Alamin. Beirut: Daar AlKutub Al-'Ilmiyyah.

Al-Jurjani, A. M. (1983). At-Ta'rifaat. Beirut: Daar Al-Kutub Al-'Ilmiyyah.

Al-Nadawi, A. A. (2000). Jambarah al-Qawâid al-Fiqhiyyah fî al-Mu'amalât al-Mâliyyah. Riyadh: Syirkah Al-Rajihi Al-Mashrafiyyah li Al-Istithmar. 
Al-Qarafi. (1990). Al-Furuq. Beirut: Darul Ma'rifah.

Al-Qardhawi, Y. (1997). Fatwa Antara Ketelitian Dan Kecerobohan. Jakarta: Gema Insani Press.

Al-Qardhawi, Y. (2014). 7 Kaidah Utama Fiqh Muamalah. Jakarta: Pustaka Al-Kautsar.

Al-Ruki, M. (1998). Qawa'id Al-Fiqh Al-Islami. Beirut: Daar Al-Qalam.

Al-Shiddiqy, H. (1994). Pengantar Hukum Islam. Jakarta: Bulan Bintang.

Al-Zarqa, M. A. (1983). Al-Madkhal Al-Fiqh Al-'Amm. Damaskus: Mathba’ah Jami’ah.

As-Subki, T. (1991). Al-Asybah wa An-Nadzair. Beirut: Daar Al-Kutub Al-'Ilmiyyah.

As-Suyuthi. (1990). Al-Asybah wa An-Nadzair. Beirut: Daar Al-Kutub Al-'Tlmiyyah.

Azzam, A. A. M. (1999). Qawa'idu Al-Fiqh Al-Islami. Kairo: Maktabah Ar- Risalah AdDauliyah.

Berlianti, Y. S. (2001). Prinsip-prinsip Hukum Perdagangan Berdasarka Ketentuan World Trade Organization dalam Perspektif Hukum Islam. Jakarta: Pascasarjana Fakultas Hukum Universitas Indonesia.

Boukercha, H. (2014). Islamic Legal Maxims and Their Application in Islamic Finance. ISRA: International Arabic Journal of Islamic Finance, 5(1).

Djazuli, H. A. (2016). Kaidah-kaidah Fikib: Kaidah-kaidah Hukum Islam dalam Menyelesaikan Masalah-masalah yang Praktis. Jakarta: Prenadamedia Group.

Fatoni, N. (2012). Penguatan Akad Pembiayaan Mudharabah untuk Merealisasikan Misi Keadilan Berbisnis pada Baitut Tamwil Tamzis Wonosobo. Economica: Jurnal Ekonomi Islam, 2(2).

Fauzi, M., Azizah, A. N., \& Nurfauziyah, L. (2020). The Concept of Ifta' in Establishing Halal Law (Study of Usul fiqh on Legal Determination Methods). Journal of Digital Marketing and Halal Industry, 1(1), 83. https://doi.org/10.21580/jdmhi.2019.1.1.4776

Gayo, A. A. (2011). Kedudukan Fatwa MUI Dalam Upaya Mendorong Pelaksanaan Ekonomi Syariah. Jakarta: Penelitian Hukum Badan Pembinaan Hukum Nasional Kementerian Hukum Dan HAM RI.

Kurdi, M. (2011). Usbul Fiqh Sebuah Pengenalan Awal. Banda Aceh: Lembaga Kajian Agama dan Sosial (LKAS).

Mudzhar, M. A. (2014). Revitalisasi Maqashid Syariah dalam Pengembangan Ekonomi Syariah di Indonesia: Studi Kasus atas Fatwa-fatwa DSN-MUI Tahun 2000-2006. Indo-Islamika, 4(1).

Muhammad al-Zarqa. (1996). Syarh Al-Qawaid Al-Fiqhiyyah. Damaskus: Dar Al-Qalam.

Neni Sri Imaniyati, Neneng Nurhasanah, \& Panji Adam. (2017). Kompetensi Pengadilan Dalam Eksekusi Putusan Basyarnas Pada Sengketa Perbankan Syariah Menuju 


\section{At-Taqaddum}

Vol. 12 No. 2 (2020) 201-222

Unifikasi Hukum. Adhaper: Jurnal Hukum Acara Perdata, 3(1).

Praja, J. S. (2015). Filsafat Hukum Antar Madz̧hab-Madð̧hab Barat dan Islam. Bandung: Sahifa.

Salam, I. A. (1999). Qawa'id Al-Abkam fi Mashalih Al-Anam. Beirut: Daar Al-Kutub Al'Ilmiyyah.

Sam, M. I. (2014). Himpunan Fatwa Keuangan Syariab: Dewan Syariah Nasional MUI. Jakarta: Erlangga.

Syafe'i, R. (1999). Ilmu Usbul Figh. Bandung: Pustaka Setia.

Syam, S. (2014). Perkembangan dan Pembukuan Qawa'id Fiqhiyyah: Sebuah Tinjauan Historis. Al-Muqaranab: Jurnal Perbandingan Hukum Dan Mą̧bab, 2(2).

Thalib, P. (2016). Pengaplikasian Qowaid Fiqhiyyah dalam Hukum Islam Kontemporer. Yuridika, 31(1). 